\title{
The Uses and Abuses of Censorship: God, Ireland and the Battle to Extend Censorship Post 1929
}

\author{
Anthony Keating \\ Edge Hill University in Lancashire, UK
}

Copyright (c) 2014 by Anthony Keating. This text may be archived and redistributed both in electronic form and in hard copy, provided that the author and journal are properly cited and no fee is charged for access.

\begin{abstract}
The passage of the 1929 Censorship of Publications Act marked a significant development for the inclusion of Irish Catholic teaching into the Free State's legal system. Notwithstanding this, many on the fundamentalist wing of Irish Catholicism felt let down by the scope of the Act. Censorship, under the Act, was limited to issues of sex, sexual morality, contraception and abortion and excluded attacks on the Catholic faith and the denial of God, all of which were viewed as blasphemy, and therefore the legitimate focus of censorship, by many of those who had lobbied for the extension of censorship. The Catholic Truth Society of Ireland (CTSI) was in the vanguard of lobbying for the introduction of the 1929 Act and played the leading role in its policing. The CTSI was unstinting in its efforts to officially and surreptitiously extend censorship. This article traces the correspondence of the CTSI with politicians, the Catholic hierarchy and a leading print distributor, in order to demonstrate how the organization sought to extend literary censorship to encompass blasphemy, through the application of moral, economic and political pressure. A campaign that had at its heart the desire to control the actions and thoughts of the Irish people.
\end{abstract}

Key Words. Blasphemy, lobbying, Irish Free State, censorship, militant Catholicism.

Resumen. La aprobación de la Ley de Censura de Publicaciones en 1929 supuso un significativo paso hacia la inclusión de la enseñanza irlandesa católica en el sistema legal del Estado Libre. A pesar de ello, muchos miembros del ala fundamentalista del catolicismo irlandés se sintieron decepcionados por el alcance de dicha ley. De acuerdo con la ley la censura se limitaba a cuestiones de sexo, moralidad sexual, anticoncepción y aborto, excluyendo ataques a la fe católica y negación de Dios, considerados blasfemia, y en consecuencia objeto legítimo de censura, por parte de muchos de los que habían ejercido presión para la ampliación de la censura. La Catholic Truth Society of Ireland (CTSI) encabezaba la campaña por la introducción de la Ley de 1929 y jugó un papel destacado en su implementación. La CTSI no cejó en sus esfuerzos para extender la censura, tanto oficial como subrepticiamente. Este artículo detalla la correspondencia de la CTSI con políticos, la jerarquía católica y un importante distribuidor de prensa con el propósito de demostrar como, por medio de medidas de presión moral, económica y política, la organización intentó extender la censura literaria para que abarcara la blasfemia. Una campaña inspirada por el deseo de controlar la actividad y pensamiento del pueblo irlandés.

Palabras clave. Blasfemia, cabildeo, Estado Libre de Irlanda, censura, catolicismo militante.

ISSN 1699-311X 
The 1929 of Publications Act was the product of pressure from well organised Catholic lay organisations $^{1}$ and the hierarchy ${ }^{2}$ of the Irish Catholic Church (Curtis 2010). The Catholic Church in Ireland was particularly authoritarian and pessimistic about the Irish people's ability to play out what it viewed to be their religionational mission, namely, to offer a CelticCatholic beacon of purity to a world otherwise sullied by sin (Keating 2012b). Ireland's population was believed, by religio-nationalist ideologues, to have been partially corrupted by centuries of imperial domination and the temptations of modernity. It was reasoned therefore, that if Ireland was to achieve its potential of true Catholic nationhood, its people required an unquestioned faith in the spiritual and moral leadership of the Catholic Church and the riddance from Ireland of spiritual and intellectual contaminants from within and without its borders (Keating 2012b). The main source of these 'contaminants' came in the shape of the cinema, for which censorship was legislated in the 1923 Censorship of Films (Rocket 2004) and the published word, which is focused upon here.

These 'contaminants' were described in warlike terms in the Catholic press of the day which warned: "Modern forces are not for but against the Church's mission. Today the enemy is invisible and omnipresent. The Irish Catholic is like a soldier who has turned aside the sword but is attacked by a poisonous gas" (Irish Monthly ${ }^{3}$,53,1925: 350). Central to this 'protection' was the censorship of newspapers, periodicals and novels that were viewed as carriers of sexual immorality and blasphemy.

1. These refer to organisations composed of laity and clerics that are not orders of the church but which function with the approval of a local bishop.

2. The Catholic Church describes as its hierarchy its bishops, priests and deacons but for the purpose of this article it refers largely to bishops, the leadership of the religious orders and other senior clerics involved in the organisational and administrative apparatus of the church.

3. The Irish Monthly was a Catholic magazine founded in Dublin by the Jesuit Matthew Russell (1834-1912), in July 1873. Intended as a devotional magazine, it was originally titled, Catholic Ireland, but rapidly became identified as a literary journal (O'Keefe, 2010). Until 1920 it had the sub-title $A$ Magazine of General Literature.
These publications were viewed as insidious vehicles of $\sin$ and corruption that the vast majority of Ireland's citizenry were too unsophisticated to resist. A concern alluded to by the Editor of the Catholic Bulletin, who observed, "the mind of England has been trained to criticise and think for itself; that of Ireland to believe and accept what it is taught" (Catholic Bulletin, 2,1928: 124).

The organisation in the vanguard of ensuring the protection of the Irish people from corruption carried in the printed word was the Catholic Truth Society of Ireland (CTSI). The Society, which has its headquarters in Dublin, was organized at the meeting of the MaynoothUnion in 1899, with the stated purpose of diffusing "by means of cheap publications sound Catholic literature in popular form so as to give instruction and edification in a manner most likely to interest and attract the general reader", and which would "create a taste for a pure and wholesome literature, and will also serve as an antidote against the poison of dangerous or immoral writings". It was then a proselytising organisation, with strong links to the Catholic hierarchy, which had an active interest in the published word.

The CTSI's first President was Dr. Healy, Bishop of Clonfert and its first lay Honourable Secretary was one John Rochford. The CTSI was overseen by a management committee made up of all the Irish hierarchy, a number of parish priests, a representative of the Jesuit Order and leading members of the Catholic laity, including a Papal Count, George Noble Plunkett, and the Papal Knight and leading physician Sir Francis Richard Cruise (The Tablet, 24.10.1903).

The CTSI's publications were numbered in the millions each year. Between 1918 and $1949^{4}$ records show they published 40 million units in Ireland, although this is thought to be a substantial underestimate (Hutton \& Walsh 2011) and whilst in 1927 its core membership numbered little more than 6000 (Hutton \& Walsh 2011), it had an extensive and nationwide activist core (Curtis 2010). By the 1920s leadership of the CTS included leading figures from the Dominican and Jesuit orders and it enjoyed widespread support across the

4. A period which represents the only published data available on the CTSI's publication figures. 
political spectrum, doubtless, in part out of conviction, but also out of the reality that not to support the organisation could lead to political suicide (Curtis 2010).

An examination of the role of the CTSI in promulgating and latterly attempting to extend censorship, in the years after 1929, highlights the tensions among the executive branch of the State. Articulate libertarians like Micheal O'Donovan (Frank O'Connor), George Russell $(Æ)$, George Bernard Shaw and Seán O' Faoláin and the views of influential and well connected Catholic pressure groups provide us with an insight into the way the Catholic Church and its lay organisations exerted their influence in Ireland for much of the next 60 years. This article will begin by contextualising the censorship debate and introduction of the 1929 Censorship of Publications Act before exploring the role of the CTSI in attempting, by stealth, to extend the Act to encompass blasphemy.

\section{The Crusade for Censorship}

In 1925, pressure was brought to bear on the Minister for Justice, Kevin O'Higgins, by the Catholic pressure group the Irish Vigilance Association of Ireland, ${ }^{5}$ the Christian Brothers and Catholic publications such as the Catholic Bulletin and Irish Monthly,t o suppress the availability in the Free State of what these groups called 'evil literature'. There had already been the introduction of strict film censorship legislation in 1923. O'Higgins was initially reluctant to act as he felt there was little popular support for this move. However, his mind was changed in 1926 following a meeting with a group of Catholic bishops and he established The Committee of Enquiry on Evil Literature (CEL) (Horgan 2001) which in December 1926 submitted a report that formed the basis of the 1929 Censorship of Publications Act.

The Committee, its report and the subsequent legislation, were driven by a core of Catholic fundamentalists and religio-nationalist activists in organisations such as the CTSI, the Irish

5. The Irish Vigilance Association was a society established in Ireland in 1911 under the auspices of the Dominicans. Its objective was to prevent the spread of "bad and unsavoury literature" by enrolling members in a "Good Literature Crusade".
Vigilance Association (aided by the Catholic Writers Guild), the Irish Retail and Newsagents Association and Catholic lay organisations, in particular the Knights of Saint Columbanus, an organisation that had a particular interest in censorship (O'Drisceoil 2005) and one that Tom Garvin has argued "became a considerable political force after independence..." (Cited in McCormack 2001: 524). Alongside these organisations, a plethora of Catholic publications, including The Standard and The Irish Catholic, exerted a profound influence on public and political opinion (Hutton \& Walsh 2011). The term 'public opinion' is used advisedly here, as the CTSI had spent much of the 1920s mobilising parish based cadres, who promoted Catholic literature and sought to extinguish the circulation of 'inappropriate' publications. This work was aided, from 1925 to 1927, with the appointment by the CTSI of a full time organising secretary. The CTSI campaign enjoyed remarkable success. For example by 1929 in Roscrea, County Tipperary, some $95 \%$ of Catholic households subscribed to Catholic journals (the figure had been virtually nil in 1925). This success was replicated across the country (Curtis 2010).

The tools for this campaign included moral pressure on individuals and threats against businesses that wouldn't tow the line, and indeed on a number of occasions extended to robbery with violence. ${ }^{6}$ An example of the reach and tactics of the CTSI's campaign is demonstrated in the case of a County Clare newsagent, a Mr Doherty, who refused the local CTSI branch request that he stop selling the Daily Express, on the grounds that "life in a country village like this is dull enough without being told what to read in one's spare moments". He was reported to the CTSI's Dublin headquarters by the local group and headquarters in turn contacted the local parish priest to increase the pressure on him to conform (Curtis, 2010, 83). The power of moral pressure on Irish Catholics exerted by the Catholic Church cannot be overstated, at personal, organisational and political levels (Inglis, 1998). This power could be used to

6. For an example of this see the report in the Irish Times on the 2.5.1927 regarding the theft of thousands of English Newspapers by a masked gang. 
alienate people from their communities, ruin businesses and careers and even alter the course of elections (Curtis 2010; Keating 2002). To be seen as not supporting the campaign was to be 'beyond the pale', for the vast majority of Free State Ireland's Catholics, some $98 \%$ of the population, there was little choice other than to support the campaign.

Consequently, during the passage of censorship legislation through the Oireachtas, ${ }^{7}$ few voices were raised during the Bill's passage, however, a number of Amendments were made that altered the reporting mechanisms for publications as being 'immoral' and the scope of what constituted immorality under the Act (Curtis 2010). The CTSI favoured the introduction of 'Recognised Associations', groups through whom all complaints must be channelled, a role they were keen on providing. This was overturned in favour of the right of any citizen to lodge a complaint.

The resulting legislation was clear in its scope in regard to issues concerning pornography, sexual immorality, sexuality, the reporting of court proceedings, advertising or promoting contraception and marital advice, and gave the Censorship Board the authority to ban those titles it found to contravene the Act from being imported or sold in the Free State. What the Act did not provide for, despite the desire of the CTSI, was to facilitate the banning of publications that advocated atheism, challenged Catholic theology or brought the Catholic Church into disrepute, in other words to bolster existing provision under Irish law for the prosecution of blasphemy, ${ }^{8}$ an ambition key to those who drove the campaign to strengthen censorship and were frustrated by the scope of the Act which "was not all a Catholic Country would desire" (Dublin Diocesan Archive (DDA), BP. Box 5).

Soon after the legislation was passed, the

7. The Oireachtas is the "national parliament" or legislature of Ireland.

8. Blasphemy had been an offence under Common Law since the $16^{\text {th }}$ century. Whilst vigorously applied for much of its history by the $20^{\text {th }}$ century it was seldom, if ever, applied.

9. Letter from O'Reilly to Dublin Dioceses re regulating censorship. 21.3.1930. battle lines over influence and the use of the Act were drawn. The CTSI immediately began to put pressure on the Government for it to support a radical interpretation of the Act in furtherance of the CTSI's own social and religious agendas.

In October 1929, soon after the passage of the Act, F. O'Reilly, ${ }^{10}$ the Executive Secretary of the Catholic Truth Society, lodged a complaint in a personal capacity to the Minister for Justice (the Censorship Board had not yet been 'convened" ${ }^{11}$ ) against a book by Warwick Deeping entitled Ropers Row. ${ }^{12}$ Mr O'Reilly claimed that the book advocated birth control. The Minister rejected O'Reilly's request that the book be censored, arguing that the book: "Whilst perhaps... treads on delicate ground could scarcely be called indecent or obscene, and the rhetorical question on page 394 in the light of the rest of the chapter could not be construed as an advocacy of contraception within the meaning of the Act" (National Archives of Ireland (NA.S2325).The offending section reads:

...Christopher Hazzard had opinions upon the conceiving and bearing of children, and they were of an opinion that were considered scandalous and decadent by the great majority of conversationalists in those years before the war....

...Does man leave nature alone? Is not our civilization a perpetual interference with natureso called?

10. F O'Reilly K.C.S.G Organising Manager and Secretary of the Society. He was a member of The Order of St. Gregory the Great which is one of the five Orders of Knighthood of the Holy See. This honour is bestowed upon Roman Catholic men and women and sometimes in rare cases to nonCatholics in recognition of their personal service to the Holy See and to the Roman Catholic Church, through their "unusual labours, their support of the Holy See, and their excellent examples set forth in their communities and their countries."

11. The Censorship of Publications Board was not constituted until January 1930.

12. Warwick Deeping (1877-1950) was a popular English writer of historical romance. Roper's Row is the story of the struggles of a disabled young man to become a successful medical doctor and of the two women who are the bedrock in his life. This was also published in serialized version in Woman's Journal Magazine, Aug. 1928-Jan. 1929. 
How many births are desired or planned?

How many children are the mere products of casual lust?

When two people can afford to rear and educate one or two children decently, does it still remain their duty to have six or ten?

What is the number of mentally defective children, potentially tuberculous children, syphilitic children born in London yearly?... (393-394).

O'Reilly took exception to his response and lodged a direct appeal to the President of the Executive Council, ${ }^{13}$ W.T. Cosgrave; ${ }^{14}$ the correspondence on this issue makes for fascinating and illuminating reading. O'Reilly informed the President, in a threatening tone: "I do not intend to let the matter rest where it stands. I shall publish the correspondence with comments, unless you may be able to induce a change of heart and a change of attitude in the Department concerned" (NA. S2325).

In a hand written letter to the Secretary of his Department, Cosgrave noted the likelihood of a growing number of correspondences on the matter of censorship and the potential for negative press coverage. Referring to the Minister for Justice, James Fitzgerald Kenney, ${ }^{15}$ President Cosgrave noted that "the Minister is in an impossible position" in trying to balance a realistic application of the Censorship Act against the "strong suppression" favoured "by such people as the Secretary of the Catholic Truth Society". The President agreed that the book did not require

13. The President of the Executive Council of the Irish Free State was the head of government or prime minister of the Irish Free State which existed from 1922 to 1937.

14. William Thomas "W. T." Cosgrave (6 June 1880 - 16 November 1965), succeeded Michael Collins as Chairman of the Irish Provisional Government from August to December 1922. He served as the first President of the Executive Council (prime minister) of the Irish Free State from 1922 to 1932.

15. James FitzGerald-Kenney (1 January $1878-21$ October 1956) was an Irish politician and Senior Counsel (A senior barrister equivalent to the British, Queens Council). He was first elected to Dáil Eireann (The Lower House of Parliament) at the June 1927 general election. He was appointed to the Cabinet on his first year in Dáil Éireann as Minister for Justice. suppression as its contents were "piffle" and it was a "mealy mouthed" complaint (NA. S2325).

However, Cosgrave, did feel that the government could gain a political advantage by referring the book to the soon to be established Censorship of Publications Board even though he felt that it should not be banned. The President claimed that a reversion of the Minister for Justice's original decision on the book by the Board would "do us good rather than no harm". The President was clearly concerned to stop challenges to the scope of the Act "within a few months of its passing." $\mathrm{He}$ went on "You must bear in mind the possibility for amending this being promoted from any one or more sources". Cosgrave clearly felt that he was trapped in a pincer movement between the CTSI's desire to extend censorship and those who advocated a minimal interpretation, or even abolition, of the Act; all of whom were jockeying for position in support of their competing agendas. Cosgrave's sense of the gamesmanship involved even extended to speculation over Warwick Deeping's intention in including the passage that had offended O'Reilly. He speculated, "as far as the material transgressing is concerned it may well be that the author had the Act in mind" (NA.S2325). ${ }^{16}$

The journey of the Censorship Bill through the Dáil had been a balancing act for the government between allaying the fears of more liberal minded members and giving the more fundamentalist groupings a sense that their concerns were being addressed. Cosgrave was clearly not ready to reopen this issue.

The threatening tone of O'Reilly's letter was not lost on the President's office. A memo dated the $6^{\text {th }}$ November 1929 states:

In my opinion the tone of the second paragraph of $\mathrm{Mr}$ O'Reilly's letter of the $25^{\text {th }}$ Ultimo, addressed to the President, is most objectionable. It is obviously an endeavour to get what he wants done by means of threats. The whole practice by which he endeavours to make the President a court of appeal from the Minister for Justice in the matter of the Censorship of Publications Act is strongly to be deprecated. To give way in this instance is, in my opinion, simply

16. Letter dated 28.10.29. 
to invite further trouble from this gentleman (NA.S2325)

This advice was not heeded. Cosgrave referred the matter back to Fitzgerald -Kenny who agreed to the President's request to refer the book on to the Censorship Board. A civil servant noted that in relation to O'Reilly: "We are unfortunately in the position of having to tell him now that his tactics have succeeded in the present instance, this I am afraid, will only invite further trouble" (NA.S2325).

A letter was drafted that sought to limit the damage with a final paragraph which was never sent which concluded: "I have to add that in considering this matter the President has not been helped by the tone of the opening sentence of the second paragraph of your letter, which he feels is excusable only in the light of your obvious sincerity". The civil servant who drafted it noted in a hand written footnote that "The President of course may not approve to the last paragraph of my letter" (NA.S2325). He was right and it would seem that even this thinly worded rebuke was seen as too strong. The President had decided to simply send O'Reilly a copy of the Minister for Justice's reply agreeing to the request.

On the $13^{\text {th }}$ November 1929 the CTSI responded to this news by informing the President that they would let the matter rest as "He [President Cosgrave] has done all in this matter that we requested him to do" (NA.S2325). The same civil servant who advised Cosgrave against this course of action noted, in his own hand, at the end of the reply that "the President should see this." It would seem that he viewed the outcome as a warning for the future. This warning was to prove salutary, as there is ample evidence in the National Archives that the CTSI contacted the President after this date to persuade him to use his influence in supporting the suppression of books, doubtless emboldened by their success, when in the May of 1930 Deeping's Ropers Row became one of the first thirteen books to be banned by the Censorship Board. This can hardly have been surprising from the time of its formation in early 1930 up until the mid 1950s, the CTSI and its allies the Knights of Saint Columbanus held a working majority on the Board (O’Drisceoil 2005).
O'Reilly and the CTSI were untiring in their efforts, placing pressure on individuals and companies to enforce the law as they felt it should be enforced despite, in their terms, the 'shortcomings' of the Act. In 1930 O'Reilly requested help from the Archbishop of Dublin with the development of a network of "volunteers" who would comb through the press to root out any publications which included material that contained:

(1) Blasphemous utterances or writings.

(2) Denials (direct or implied) of the Divinity of Christ.

(3) Pleas for spiritualistic practices.

(4) Attacks on the Catholic Church - its doctrines, its practices, its government.

$$
\text { (DDA. BP. Box 5). }{ }^{17}
$$

In essence, the CTSI was attempting to reinvigorate the laws in regard to prosecuting blasphemy, as by the mid 1920s the Common Law offence of blasphemy was largely redundant, having fallen out of use. ${ }^{18}$

Censorship was envisioned and campaigned for by the CTSI as a building block of what they hoped was a road to the establishment of a Catholic-compliant State, constituted democratically but directed doctrinally. In the June of 1925, the CTSI had submitted for publication in the Irish Catholic, an article which asserted, "our politics must be governed by religion. Where politics and religion are in conflict religion is right and politics is wrong. Taking our religion from Rome, therefore, we take our politics too" (DDA. BP. Box 5). Cosgrave and all bar one of his cabinet, Ernest Blythe, were Catholic and doubtless O'Reilly felt that with the right amount of moral pressures that they could be persuaded to act in accordance with their Catholic loyalties. The article was rejected by the editor but the CTSI continued to work tirelessly towards this goal.

Despite the removal of the 'Recognised Association' section from the Censorship Bill, the CTSI drove the work of the Censorship

17. Letter dated 21.3.1930.

18. The last attempted usage of the law had been in 1855. 
Board in the teeth of determined public nonengagement with the process. The Censorship Board complained in its first Annual Report that:

The failure of the general public to co-operate in making the Censorship a success is a matter of great regret to us....We regret to say with the exception of the Catholic Truth Society of Ireland, which has furnished the majority of complaints received, little assistance has been obtained from those sources (Censorship Board Annual Report, 1931).

The Irish public were passive recipients, rather than active supporters of the pronouncements of the Censorship Board. O'Higgins, the Minister who had initially declined to extend censorship, had been correct in recognising the lack of public appetite. Those members of the public who could afford to do so, sought to import banned material surreptitiously (O' Drisceoil 2005) whilst the vast majority put up with, rather than supported, censorship. Whilst commentators, including Robert Walsh, have asserted that "an increasingly pious set of public opinions on morality, sex and belief ... had formed very quickly after the foundation of the Free State as if in a reaction to the anarchy of revolution and its aftermath" (Walsh, 1999: 4) the reality is more nuanced. Literary and wider cultural evidence suggests that the social mores described elsewhere as the persistence of Victorian puritanical values in the Free State (Valiulis 2009; Keating, in press.) were centred on a religious cohort who had to expend energy on enforcing their brand of sexual Puritanism on a less than universally predisposed populace $;{ }^{19}$ a populace who complied with, at

19. Arensberg \& Kimbal's Family and Community in Ireland, was a social anthropological study arising from an interdisciplinary research programme undertaken in Ireland in the 1930s known as the 'Harvard Irish Survey' (1931-1936). The major focus of the work was on County Clare. The study described patterns of sexual attitudes that did not fit the Free State's view of sexual propriety and indicated that, to some degree, Free State ideologues were imposing their views on sexual morality rather than protecting existing native virtues. Another important text in gauging the realities of sexual life in the Irish Free State is The Tailor and Ansty by Eric Cross, published in 1942, a book about the life of the Irish tailor and storyteller, Timothy Buckley, and his wife Anastasia. least in public, rather than actively supported the moral agenda that censorship or its extension represented. A reality underscored by the evidence relating to the extraordinary efforts priests would have to put into policing their flocks to prevent 'occasions of sin', dancing and drinking and their reports of this activity to the hierarchy and police (Crowley \& Kitchin 2008; Keating 2012a), the actual rates of sexual crime in the Free State (Keating 2012a), the real rates of illegitimacy (Crowley $\&$ Kitchin 2008), the evidence presented to the Carrigan Committee ${ }^{20}$ (Finnane 2001), the extensive desire of the populace to read the British press, despite its religious leaderships protestations $^{21}$ (Dail-debates, Volume 26. 18. 10. 1928), and the frank admission of the Jesuit, R.S. Devane, a leading censorship campaigner, amongst others, that the Irish people were simply not that interested in extending or supporting censorship (Horgan 1995).

To raise your voice publically against censorship could lead to the full force of the moral and economic weight of the Catholic Church being brought against you, a force that could lead to social alienation and professional and economic ruin. To be anti-censorship was to be anti-church and anti-Irish (Keating 2012b), leading you to being denounced as what the Editor of the Catholic Bulletin referred to as "those low creatures, vulgarians, wastrels, materialists, mere Irish scum" (March 1927:233). The Irish government, as well as the ordinary citizen, had to be cognisant of the power of the Catholic Church. As Seán O'Faoláin, writing in the literary journal, The Bell, in the June of 1951, speaking of the

20. In 1930 the Minister for Justice, James Fitzgerald-Kenney established the Committee on the Criminal Law Amendment Acts and Juvenile Prostitution under the Chairmanship of William Carrigan QC. The Carrigan Report was presented to government in1931 and played a significant role in the creation of the Criminal Law Amendment Act (1935). However, the report was suppressed from public consumption due to the shocking revelations relating to sexual crime in the Free State. The report was not available for public scrutiny until its release to the National Archives in 2000.

21. Professor Thrift, a CEL member speaking in Dáil Éireann. 
Taoiseach, ${ }^{22}$ said:“ When the Catholic Church through its representatives speak, he realises, and the Roman Catholic public realises, that if they disobey they may draw on themselves this weapon whose touch means death" (11). A description as apt in the 1930s as it was in the 1950 s, an era when it was marginally safer to voice the un-voiceable. Not everyone, however, was prepared to tow the line.

\section{Freedom of Speech vs. Divine Law}

A correspondence between O'Reilly and a book and periodical distributor is worth quoting at length as it perfectly demonstrates the ideological battle line drawn around censorship. In the March of 1934 O'Reilly embarked on a correspondence with Charles Eason, the Protestant owner of the main book and periodical retailer and distributor in Ireland, in which O'Reilly castigated him for distributing a title that the Catholic Truth Society viewed as inappropriate for an Irish audience, The Freethinker, ${ }^{23}$ a secular humanist magazine with an avowedly anti- religious stance, an action which O'Reilly felt was 'inconsistent' with the fact that Eason's distributed Catholic publications. Eason replied that he was "sorry that [O'Reilly did not] approve of the lines on which our business was conducted" but that he recognised no such 'inconsistency' (DDD. Byrne papers (BP) Box 5). ${ }^{24}$ O'Reilly replied

22. The Irish 'Prime Minister'.

23. The Freethinker is a British secular humanist magazine, founded by G.W. Foote in 1881. It always took an uncompromising anti-religious stance with Foote declaring in its first issue: "The Freethinker is an anti-Christian organ, and must therefore be chiefly aggressive. It will wage relentless war against Superstition in general, and against Christian Superstition in particular. It will do its best to employ the resources of Science, Scholarship, Philosophy and Ethics against the claims of the Bible as a Divine Revelation; and it will not scruple to employ for the same purpose any weapons of ridicule or sarcasm that may be borrowed from the armoury of Common Sense". Whilst Foote was prosecuted for 'Blasphemy' in 1882 and sentenced to 12 months imprisonment, the magazine has continued publication to this day despite its content being offensive to the Catholic Truth Society.

24. Letter dated 7.3.1934. vociferously on the 8.3.34 reasserting Eason's perceived 'inconsistency' and making a veiled threat, asserting:

Your firm is one of the largest suppliers of Catholic Prayer Books, and if I wrote a letter to the public press, protesting against the circumation (sic) of "The Freethinker" in Ireland; and stated in that communication that copies could be obtained on order through your firm, I think the public would be quick to note the incongruity..... (DDA. BP. Box 5). ${ }^{25}$

This represented a return to an older threat against Eason's during the work of the Committee on Evil Literature when Charles Eason had written to the Irish Independent newspaper to suggest that there was no need for further legislation (Horgan, 1995).

Eason replied on the 9.3.1934:

...You are contrasting a personal opinion with the policy adopted by my firm regarding its duties to the public.

We provide machinery for enabling the public to obtain what they want from publishers with whom they could not otherwise come into contact. Experience shows that this service must be carried out in an impartial and unbiased manner, quite regardless of personal feelings.

Eason reinforced the point by noting: "E.g. I am a teetotaller, but my firm advertises alcoholic drinks" (DDA. BP. Box 5). ${ }^{26}$

O'Reilly's reply on the 12.3.1934 and the response from Eason, encapsulate the ideological distance between the opposing factions regarding the issue of freedom of expression within the Free State: O'Reilly wrote:

No duty to the public can run counter to a duty to God. The people who deny the existence of God are to be pitied, but not helped to disseminate their insanity. A Catholic thinks that his religion must influence all his conduct and the conduct of his firm; and I thought that thoughtful Christians of other religions were guided in the same way.

O'Reilly finished with what by now was a standard economic threat:

I do not think Catholics would like to give their business to firms who were prepared, regardless

25. Letter dated 8.3.1934.

26. Letter dated 9.3.1934 
personal feelings, to supply atheistic literature. Even Catholics have personal feelings, if I may say so, to supply atheistic literature in a country that is $93 \%$ Catholic, it is their personal feelings that should count (DDA. BP. Box 5). ${ }^{27}$

\section{Eason replied:}

I quite agree with you that religion should influence all our conduct, but we differ as to what is the attitude which the teaching of Christ requires in reference to freedom of discussion.

I think the right method of countering erroneous opinions is by free discussion, and by the following of Christ in our daily life; but this view must be quite familiar to you, and I do not think it necessary to enlarge upon it (13.3.1934. DDA. BP. Box 5).

O'Reilly's reply invoked two powerful motifs; scripture and nationalism:

I certainly cannot remember any text of Scripture, in which Christ pleaded for free discussion as to the existence of God. We lock up insane people, for fear they would do us or themselves bodily harm; but you would have us distribute insane literature to poison our reason and all in the sacred name of liberty of discussion. Men like Roger Casement were hanged for treason of an earthly king; and yet you would permit treason to the King of Kings (14.3.1934 DDA. BP. Box 5).

At this point Eason sought to end communication on the issue but O'Reilly persisted. On the 20.3. 1934 Eason concluded his correspondence with O'Reilly by pointing out that only 12 copies a week of The Freethinker were sold in Ireland and that if O'Reilly chose to write to the press on the issue, the publicity may well cause an increase in sales. It would seem that this logic may well have resonated with O'Reilly and in a facesaving and hypocritical reply, he wrote to Eason on the $21^{\text {st }}$ of March asserting:

I am in receipt of your letter of the $20^{\text {th }}$ instant, and note that you have no objection to my stating in public that you supply copies of "The Freethinker." While I do not agree with your view that publishing our correspondence would be likely to increase the sale of "The Freethinker", I do not intend at this stage to raise the matter in public, because I think it might affect your business; and I have no intention of

27. Letter dated 12.3.1934. acting in any unfriendly ${ }^{28}$ or uncharitable way (DDA. BP. Box 5).

O'Reilly's concern for Eason's business would seem to be rather superficial, as on the same day he wrote to Archbishop Byrne's secretary, Father Dunne, with a complete copy of the correspondence between him and Eason stating:

I am not inclined to write a letter to the press about "The Freethinker" at this stage; but I think the fact that Messrs Eason \& Son supply this paper should be made known to all the Hierarchy. After all, if this firm persists, I think in justice to Catholicism, and as a vital principle is involved, all Catholic business, or at least all clerical business, should be withdrawn from the house; and if all priests and nuns stopped dealing with the firm, they would probably be prepared to change their tune (DDA. BP. Box 5).

There is no evidence that the hierarchy acted on O'Reilly's suggestion to the Archbishop, however, evidence does exist that the desire of the CTSI to use the Censorship Act as 'back door' blasphemy legislation bore fruit, at least on occasion.

\section{The Adventures of a Black Girl in Her Search for God}

The misuse of the 1929 Censorship Act to suppress perceived blasphemy, with government collusion, is illustrated by a case concerning the writer the Catholic establishment loved to hate. In 1932 George Bernard Shaw published a story entitled The Adventures of the Black Girl in Her Search for God. It was duly banned by the Censorship Board, on the grounds that the "book in its general tendency was indecent." In June 1933 a group of Irish writers, consisting of W.B. Yeats, F.R.Higgins, George W. Russell (Æ) and Michael O'Donovan (Frank O'Connor), made representation to the Minister for Justice. They argued that the banning of the book as outlined by the Board was not justified. The group requested that the Minister use his powers under Section 8 of the Act to revoke

28. The file copy available is a proof and the word 'unfriendly' is written in pencil under the struck out typed word 'unjust'. Clearly O'Reilly felt an admission of potential unjustness was a step too far. 
the decision of the Board. ${ }^{29}$

The Minister promised the group that he would look into the matter. A reply from the Secretary to the Board dated the $3^{\text {rd }}$ of July 1933 states:

In our opinion this book is a blasphemous composition, deliberately offensive to the cherished sentiments of the vast majority of the people, irrespective of religious opinion ... but under the statutes governing our proceedings, we are not allowed to determine our decisions by considerations of this character.

The Secretary concluded that there was virtually no hope of the Attorney General bringing a prosecution under the Blasphemy Law.

However, quite apart from such considerations, the Board was unanimously of opinion that the book was objectionable in its reference to sex, indecent and general tendency, and liable to corrupt in sexual matters. In coming to this considered opinion the Board was largely influenced by the book's attitude of contemptuous disregard of the usually accepted standards of morality, in conjunction with the coarseness and vulgarity of its illustrations (NA.H315/43).

This view of the book was not supported by a minute to the Secretary of the Department of Justice, penned in July 1933, which advised: "It is difficult to find in this book substantial justification for the statement that it 'was objectionable in its references to sex, indecent in its general tendency, and liable to corrupt in sexual matters." In a handwritten note at the end of this document the Secretary advices the Minister that: "It may be dangerous to over-rule the Censorship Board. The Board is doing good work. They do not appear to be unreliable and they are working voluntarily" (NA.H315/43).

29. Section 8.- (1) state: The Minister may at any time after consultation with the Board by order revoke any prohibition order theretofore made by him under this Act. (2) Where a prohibition order has been made by the Minister under this Act in relation to a book, the Minister may at any time, after consultation with the Board, by order amend such prohibition order by excluding from the application thereof any particular edition of such book whether published before or after the date of such prohibition order.
The Secretary of the Department of Justice then sought advice from the Attorney General's Office. The reply is illuminating. The author, Conor A. Maguire, suggests in his advice that whilst there was ample evidence that the book was blasphemous:

There is more difficulty in finding evidence to support the findings of the Board that the book is in its general tendency indecent. The illustrations do feature prominently the naked body of the black girl. In the eyes of the Board this appears to lend an atmosphere of coarseness and vulgarity.

\section{Maguire goes on to suggest:}

I consider the book from beginning to end an extremely clever attack upon the fundamental basis of the Christian religion. It is subtle in the extreme and its free circulation would provoke trouble. There is no doubt that clergymen of all denominations would feel outraged if it were to get the imprimatur of the Minister. Its attraction or danger lies in the attacks upon the Christian and other religions, lightly dressed in Shavian garb. The withdrawal of the ban would stimulate interest in the book and cause a demand much greater than if it had not been the subject of the ruling by the Board. For these reasons I consider that it would be a serious matter for the Minister to interfere with the ruling of the Board even though he may feel that if he were deciding the question for the first time he would have taken a different view from theirs (NA. H315/43). ${ }^{30}$

The Minister was clearly advised that whilst the basis of the ban was flawed and he had the power to overturn it, the best course of action would be to leave well alone, whilst Shaw's book was not indecent within the terms of the legislation, it was a well constructed argument against Christianity and that the banning of the book on immorality grounds was the only vehicle open to the Censorship Board.

Whilst it may be difficult to decide from a contemporary perspective how shocking the text of The Adventures of the Black Girl in Her Search for God may have been, it is certainly the case that the woodcuts mentioned that illustrate the book were not shocking. Indeed their banning would have necessitated the emptying of most art galleries. Shaw's book

30. Letter dated 24 July 1933. 
would appear to have been placed on the banned book list because it was a wellarticulated argument against religion; but this motivation was presented in the guise of preserving the public from sexually indecent literature. The book also outraged religious opinion in Britain, there however, it gained a notoriety that led to its serialisation and a print run into 5 editions.

\section{Conclusion}

The evidence from the censorship debate, and the use of the subsequent censorship legislation, illustrates how a small and highly organised group of Catholic nationalists drove the introduction of the 1929 Censorship of Publications Act through effective political lobbying and locally based campaigning that utilised the socio-cultural capital of the Irish Catholic Church to develop a constituency of compliance, at governmental and community level, in furtherance of their religio-nationalist agenda.

Their activities had, at its core, an ideologically constructed view of an Irish Catholic society, which was anti-materialist and free of many of the vices suffered by the outside world. To this end, any publications which were identified as running counter to the prevailing moral precepts of the Catholic Church or negatively affected the view of Ireland as a beacon of purity and faith, had to be restricted as effectively as possible. Those who favoured a far deeper censorship felt ill served by the inability of the 1929 Act to ban material it felt to be blasphemous. Immediately on the introduction of the Act, the CTSI set about a campaign of political, economic and moral pressure to ensure that their aspirations were fulfilled.

The CTSI became the major conduit to the Censorship Board of complaints under the Act, in the face of evident public disengagement with the process. The CTSI fought in the years following the introduction of censorship to extend its scope to become a de facto replacement to a largely defunct common law offence of blasphemy. In part, the CTSI was aided in this mission by senior government ministers including the President of the Executive Council and the Minister for Justice, who chose not to use power under the Act to overturn a banning of a publication by the
Censorship Board when a book was patently not 'indecent' no matter how 'blasphemous' it may have been. The Cumann na nGaedheal Government of William Cosgrave was caught on the horns of a dilemma, dependent upon and respectful of, church power and authority, whilst being committed to the development of modern democratic nationhood which had at its heart a belief of freedom of action and expression; tensions that remained in place for decades to come despite Eamon de Valera's introduction of the 1937 Constitution which facilitated a more robust assault on 'blasphemy' under Irish law. Article 40.6.1.i. of the 1937 Constitution states "The publication or utterance of blasphemous, seditious or indecent matter is an offence which shall be punishable in accordance with law" and Article 44.1 states "The State acknowledges that the homage of public worship is due to Almighty God. It shall hold His Name in reverence, and shall respect and honour religion."

The Catholic lay organisations that supported censorship and its extension may been seen as a small, influential and powerful pressure group which claimed its moral authority from the Catholic Church's claim to represent $98 \%$ of the population of the Free State. A much smaller and less influential group of artists, freethinkers and intellectuals opposed censorship from within and without the State. Irish writers living in Britain, Europe and the United States did so on the grounds of artistic freedom and on the grounds that literary censorship as interpreted by the inbuilt religious minority that controlled the Censorship Board would make Ireland a laughing stock, something eventually recognised by the State in the 1950s (Comyn 1969).Those who opposed censorship were a group often vilified, treated with derision and branded as traitors by the more influential procensorship lobby and they ultimately proved less than effective in stemming the power of the censorship. Their bohemianism, foreign residency and or Protestantism where all used to discredit their views, providing them with an image problem that when compounded by their lack of the organisational coherence and cultural capital, enjoyed by the pro-censorship lobby, left them marginalised in the debate.

The censorship debate, both pre and post the 
passage of the Bill, is illustrative of the impunity with which powerful individuals and organisations could deploy surreptitiously their cultural, economic and social capital in an attempt to control the actions and thoughts of the Irish people for the sake of wider religionationalist goals.

The CTSI was to remain actively engaged in ensuring that censorship was enforced rigorously over the next 40 years. Its desire for the development of the law in regard to blasphemy was, at least partially achieved in 1937, with the introduction of a new constitution, which marked the end of the Free State and the birth of Eire. The CTSI had, at least in part, won the protection of their Catholic beliefs it had so long desired. The
CTSI's power and influence was to slowly wane over the decades as the forces of modernity made themselves felt in Ireland. Notwithstanding this the CTSI's desire to protect the name of God and religion was recently enshrined in Irish law, albeit with a far from Catholic centric focus desired by the CTSI, in the shape of the 2009 Defamation Act. An Act that traces its lineage back to the 1937 constitution framed in an Ireland in which the CTSI had great social and cultural sway; an ironic partial success for the CTSI deepest aspiration in an increasingly secular, outward looking State that exists in an era in which censorship as envisioned under the 1929 Act is unenforceable and increasingly unimaginable.

\section{Works Cited}

Arensberg, Conrad, M. \& Solon, T Kimbeall. 2001[1940]. Family and Community in Ireland. Ennis: CLASP Press

Brown, Terence. 2010. Ireland: A Social and Cultural History 1922-2002. London: Harper Perennial.

Bunreacht Na Heireann 1937. The Constitution of Ireland. Dublin: Stationery Office.

Comyn, Andrew F. 1969. “Censorship in Ireland”, Studies: An Irish Quarterly Review, Vol. 58, No. 229 (Spring), 42-50.

Curtis, Maurice. 2010. A Challenge to Democracy: Militant Catholicism in Modern Ireland. Dublin: The History Press.

Cross, Eric. 1981[1942]. The Tailor and Ansty. Dublin: Mercier Press.

Crowley, U. Kitchin, R. 2008. "Producing 'decent girls': governmentality and the moral geographies of sexual conduct in Ireland (1922-1937)", Gender, Place and Culture, Vol. 15, No. 4 (August), 355-372.

Deeping, Warwick. 1929. Roper's Row. London: Cassell \& Company.

Finnane, Mark. 2001. "The Carrigan Committee of 1930-31 and the "Moral Condition of the Saorstát", Irish Historical Studies, Vol. 32, No. 128 (Nov.), 519-536.

Horgan, John. 1995. "Saving us from Ourselves: Contraception, Censorship and the Evil Literature Campaign of 1926”. Irish Communications Review Vol 5, 61-67.

2001. Irish Media, A Critical History Since 1922. London: Routledge.

Hutton, Clare \& Walsh, Patrick (eds). 2011. The Oxford History of the Irish Book, Volume V: The Irish Book in English, 1891-2000. Oxford: OUP.

Inglis, Tom. 1998. Moral Monopoly: Rise and Fall of the Catholic Church in Modern Ireland, $2^{\text {nd }}$ revised edition. Dublin: UCD Press.

Keating, Anthony. 2002. Secrets and Lies. Unpublished PhD thesis, Dublin City University. 2012a. "Sexual Crime in the Irish Free State: Its Nature, Extent and Reporting". Irish Studies Review (May), 20:2. 137-158. 2012b. "The Case Against the Waterford Standard", New Hibernia Review (Summer), 16: 17-32. . (In Press). "Women their Own Worst Enemy". Crimsoc: The Journal of Social Criminology.

McCormack, W.J (ed). 2001. The Blackwell Companion to Modern Irish Culture. London: Wiley-Blackwell 
O’ Drisceoil, Donal. 2005. “"The best banned in the land': censorship and Irish writing since 1950”, Yearbook of English Studies 35. (Jan), 146 (16).

O'Keefe, D. 2010. “A Beacon in the Twilight: Matthew Russell, S.J. and the "Irish Monthly”, Studies: An Irish Quarterly Review, Vol. 99, No. 394, Clergy, Writers And Intellectuals (Summer), 169-179

Rockett, Kevin. 2004. Irish Film Censorship: A cultural journey from silent cinema to internet pornography. Dublin: Four Courts Press.

Valiulis, Mary. G (ed). 2009. Gender and Power in Irish History. Dublin: Irish Academic Press.

Waugh, Evelyn. 2000 [1930]. Vile Bodies. London: Penguin.

Welch, Robert. 1999. The Abbey Theatre 1899-1999: Form and Pressure. New York, Oxford: UP94.

\section{Newspapers/periodicals}

\section{Irish Times}

Irish Monthly (August 1925).

Catholic Bulletin (March 1927 \& February 1928).

The Bell (June 1951).

The Freethinker

\section{Archival Sources.}

Dail-debates.

Dublin Diocesan Archives.

National Archives of Ireland.

Censorship Board Dublin.

Received 3rd October $2013 \quad$ Last Version $1^{\text {st }}$ November 2013

Anthony Keating is a Senior Lecturer in Social Sciences at Edge Hill University in Lancashire, UK. He completed his PhD at Dublin City University in 2002 and was awarded a Government of Ireland Post-Doctoral Research Fellowship. He has published on child welfare and maltreatment, sexual crime and censorship in Ireland; most recently in Irish Studies Review, New Hibernia Review and the Journal of Church and State. 